\section{B A Institute of \\ YK Business Administration \\ 六下 \\ Karachi \\ Leadership and Ideas for Tomorrow}

Business Review

Volume 11 Issue 1 January-June 2016

$1-1-2016$

\title{
Impact of acquisition on cost efficiency of acquirer firms by using Data Envelopment Analysis (DEA)
}

Tahira Awan

International Islamic University, Islamabad

Syed Zulfiqar Ali Shah

International Islamic University, Islamabad

Arshad Hassan

Capital University of Sciences and Technology, Islamabad

Follow this and additional works at: https://ir.iba.edu.pk/businessreview

\section{(c) (1)}

This work is licensed under a Creative Commons Attribution 4.0 International License.

\section{Recommended Citation}

Awan, T., Shah, S. A., \& Hassan, A. (2016). Impact of acquisition on cost efficiency of acquirer firms by using Data Envelopment Analysis (DEA). Business Review, 11(1), 69-84. Retrieved from https://doi.org/ 10.54784/1990-6587.1079

This article is brought to you by iRepository for open access under the Creative Commons Attribution 4.0 License and is available at https://ir.iba.edu.pk/businessreview/vol11/iss1/7. For more information, please contact irepository@iba.edu.pk. 


\title{
ARTICLE
}

\section{Impact of Acquisition on Cost Efficiency of Acquirer Firms by Using Data Envelopment Analysis (DEA)}

\author{
Tahira Awan \\ International Islamic University, Islamabad \\ Syed Zulfiqar Ali Shah \\ International Islamic University, Islamabad \\ Arshad Hassan \\ Capital University of Sciences and Technology, Islamabad
}

\begin{abstract}
Using Data Envelopment Analysis techniques to calculate cost efficiency measures among firms that have carried out acquisitions, this study finds statistically insignificant improvements in cost efficiency three years after the acquisition for both financial and non-financial firms in Pakistan.
\end{abstract}

Key Words: Acquisitions, cost efficiency, Data Envelopment Analysis

\section{Introduction}

Gaining corporate control over other firms (acquisitions) has become evident in financial and economic environment as a major force of progress; moreover, it is rapidly changing due to competition, demand of new products, change in people needs/wants, emerging markets, customers and advance technology. Primarily developed countries particularly US and UK followed this amalgamation trend whereas on the other hand, most of the developing countries started to pursue the same trend. In twentieth century high growth rate is known from the fact that US witnessed a three-fold raise in number of consolidations (Acquisition) while it has been reported as five-fold raise in term of value (Copeland et al, 2005).

In UK the number and value of the consolidations were also following the same trend as of US. As in 1995 the worth of consolidation raised to 32600 million pound which was 2532 million pound back in 1972 (Arnold, 1998). The wave of acquisition has highlighted the efficiency implications of deposit taking institutions consolidations. Berger et al. (1993, p. 232) studied the interest of policy-makers and other concerned parties in this process of acquisition as if competition among financial and non-financial industry will increase, and if these acquisitions are successful in enhancing efficiencies of these industries and this will accrue substantial benefits to the customers and claimholders of these firms.

Consequently, this booming trend of acquisition motivates the researchers to study and dig out hidden motives and consequences of these consolidations. As enhancement of efficiency in acquisition is one of the two critical components of economic growth. Khan \& Senhadji, (2000) studied the linkages between the financial development and economic growth, create an urge forantitrust authorities, regulating authorities, researchers and practitioners to get better understanding of causes and consequences of financial sector consolidation.

Impact of acquisitions on performance and cost efficiency has gained more concentration due to its importance; moreover, consolidations of firms enhance efficiency in many ways. For instance, there are four rationales behind acquisition of another firm; 
Performance efficiency is the first motive which is achieved by improving firm's revenues by combining a superior mix of inputs and outputs. Profit efficiency takes both cost and revenue effect of the choice of output vector in account. Second motive is to gain cost efficiency, a firm working on cost efficiency produces certain level of output with least amount of cost, whereas profit efficient firm attain maximum profit from specific level of inputs and outputs.

Third motive is to gain post acquisition efficiency (synergy effect) and this increase in efficiency results from the changes in input output mix after merger. Fourth motive is that consolidation can increase revenues by exercising market power as an increase in market share allow them to charge high prices (extracting more from consumers') for goods and services without improving efficiencies. (Muhammad A. and Zahid A., 2014)

Consolidations occur between firms as it creates synergy among acquirer and the target firm and then synergy increases the worth of the firm, according to value increasing school of thought (Hitt et al., 2001). The theories propose that acquisitions will only take place when it is anticipated that it will create attainable amount of synergy that is valuable for both. The target firm would not sell the shares or let the bidder firm to acquire, if the gain were not positive. Therefore, efficiency theory predicts that acquisitions result in value creation for both the acquirer and the target firm.

Moreover, the theory of market poweris also a legitimate reason behind acquisitions (Houston et al., 2001; Mukherjee et al., 2004). According to Feinberg(1985), increase in allocative synergies put forward significant and positive benefits, as a firm with market power can earn large profit by charging high prices due to consumer surplus demand. Prager, (1992), Chatterjee, (1986), Kim and Singal, (1993), Sapienza, (2002), and Cefis et al., (2008) conducted numerous studies and concluded that certainly, increased profits and decreased sales are witnessed by firms after consolidation.

However, the comparative study of impact of acquisitions on cost efficiency of financial and non-financial industry is still the area to be explored. To fill the gap this scheme of study is design to investigate the impact of acquisition on cost efficiency of financial and non-financial sectors of Pakistan by using Data Envelopment Analysis (DEA) approach. Study is organized as follows. Firstly, previous researches have been discussed, then methodology of research design has been explained. Later on, results are discussed along with discussion and then conclusion is being drawn.

\section{Literature Review}

Rhoades (1993) suggests that efficiency impact on acquisitions became the central focus in the literature in late 1980s. Cost efficiency phenomenon is tested mostly in the financial sector particularly in banking sector. Researchers have applied both parametric and non-parametric tests to evaluate the bank mergers efficiency. Rhoades (1993) used the Logit model to study the 898 U.S. bank merger data (1981-89). The results of this research could not support the improvement in cost efficiency as a result of merger.

Favero andPepi (1995) evaluated the efficiency of 174 Italian banks in 1991. They used a comprehensive technique to compute scale efficiency and technical efficiency through the data envelopment analysis (DEA) model along with traditional regression model. Vennet (1996) used the stochastic frontier cost function to conduct an empirical study on the 492 European Union credit institution mergers during the 1988-92 periods. Findings revealed that bank mergers having adequate scale produced significant cost efficiency, but bank mergers would not result in economies of scale. Peristiani (1997) employed the distribution-free approach to analyze the 4,900 commercial and savings bank mergers in the U.S. during the 
1980-90 periods. Findings showed no significant post-merger efficiency but mergers created economies of scale.

Akhavein, Berger, and Humphrey (1997) replaced the traditional cost efficiency analysis with the profit function and conducted a distribution-free empirical study on the USD 100M+ U.S. commercial banks during the 1981-89 period. Findings revealed that mergers could reduce cost and improve profit efficiency of banks. Resti (1997) simultaneously used the parametric approach and DEA to compare the operating efficiency of 270 U.S. banks. Empirical findings of the two approaches did not show significant differences, the only difference were in the properties of the two approaches. Bauer, Berger, Ferrier, and Humphrey (1998) simultaneously used four approaches (DEA, stochastic frontier cost function, thick frontier analysis, and distribution-free approach) to measure the efficiency score of 683 USD 100M+ U.S. banks during the 1977-88 period. Empirical findings revealed that the three other approaches obtained more consistent efficiency score, moreover the efficiency scores were higher than that of the DEA derived efficiency score. DEA technique is used to determine cost efficiency in health sector by Yu K. 2011.

Lang and Welzel (1999) based on an unbalanced panel of all Bavarian cooperative banks for the years of 1989 included information on 283 mergers, using a frontier cost function with a time variable stochastic efficiency. It has been shown that positive scale and scope effects from a merger arise only if the merged unit closes part of the former branch network. Lin P (2005) worked on a sample of banks in Taiwan to determine mergers and their effect on cost efficiency. Banking sector witnessed a high growth rate of M\&A activities after Asian financial crisis of 1997. This study was worked on 46 banking mergers from 1997 to 1999. The results are quite interesting. The effect of mergers on cost efficiency is dependent upon culture of banks. In case of same nature of banks, no improvement was observed after the banking mergers.

Wen (2002) recognized important advancement in technical and allocative efficiency and unimportant cost efficiency advancement after bank acquisitions in Taiwan using DEA. Worthington (2001) calculated the difference between pre-acquisition and post-acquisition efficiency of the non-financial institutions. He used the discrete choice regression model and his results revealed that there was significant improvement in efficiency of Australian credit unions after the acquisitions during the time period of 1993-95. Sufian \& Fadzlan (2004) used the non- parametric frontier strategy of Data Envelopment Analysis (DEA) to explore the technical and scale efficiency of domestic integrated Malaysian commercial banks during the period of 1998 to 2003. Their findings showed improvement in efficiency in the post acquisitions period.

Gourlay et al (2006) observed efficiency gains from bank acquisitions in India by using the technique of Data Envelopment Analysis. Al-Sharkas et al. (2008) used the techniques of Stochastic Frontier Analysis (SFA) and Data Envelopment Analysis (DEA) to inspect the effect of acquisitions on cost and profit efficiency of the US banking sector. Their results suggest the confirmation of enhancement in both types of efficiencies after the acquisitions.

However, the impact was positive in case of different cultures of banks. The possible reason may be the more chances of innovation in case of heterogeneous banks. Size factor also affected the efficiency and small banks outperformed large banks in this scenario.

Some studies show that acquisitions result in no significant improvement in efficiency. Rhodes (1986) studied 413 acquisitions during the time period of 1968-78 in US. $\mathrm{He}$ used the multiple regression and probit analysis and found no improvement in the 
efficiency of acquirer banks aim comparison to the non-acquirer banks. Rhodes (1993) summarized the thirty nine US studies conducted on efficiency, profitability and stockholder wealth impact of acquisitions during the time span from 1980 to 1993 and gave little proof to the proposition that bank acquisitions consequence in improvement in performance.

The available literature propose that although there are several studies on efficiency analysis of different sectors in Pakistan but little has been explored about efficiency impact of acquisitions in both the financial and non-financial sector of Pakistan. Pakistan's financial sector has been studied from various perspectives such as Akhtar (2002) explored the Xefficiency of banks in Pakistan banking.

Mehmood \& Loan (2006) studied the impact of financial liberalization on cost efficiency of Pakistani banks between 1994 and 2000. They used the Stochastic Frontier Approach technique and observed a U-shaped efficiency pattern over the said time span and conclude that foreign banks are more efficient than domestic private bank. Their results showed no considerable relationship between bank size and efficiency. Qayyum \& Khan (2007) explored the X- efficiency, scale economies and technological growth of 29 commercial banks in Pakistan.

They used the Deterministic Frontier Approach (DFA) technique and concluded that domestic banks were not as much efficient than foreign banks during the span of 20002005.They also observed higher scale economies for small banks. Manufacturing firm of Pakistan go for expansion by means of acquisition and how these consolidation effect on financial performances was studied by Muhammad Ahmed and Zahid Ahmed in 2014.Efficiency gains of acquisitions have been a topic of significant discussion in empirical and practical research. However, the evidence concerning the efficiency impact of acquisitions in literature is diverse. Resultantly, the acquisitions in both financial and nonfinancial sectors got thrust which resulted in a noteworthy interest in investigating and exploring the efficiency impact of financial sector acquisitions from diverse angles.

\section{Methodology}

The purpose of our study is to find the relationship between acquisitions and cost efficiency and investigate if efficiencies of financial and non-financial firms are enhanced or decreased after acquisition. The nature of this study is Causal as it describes the cause and effect relationship between acquisitions and cost efficiency.

\section{Data collection, Selection of Sample and Variables}

This study investigates the cost efficiency of acquirer firms of Pakistan. The population consists of all the financial and non-financial firms which have faced acquisition of shares above 51\% that is mentioned by the competition commission of Pakistan. The study sample includes both financial and non-financial firms (Worthington, 2001)

The financial and non-financial firms, whose data was not available, were excluded from the sample. The foreign firms who have acquired the target Pakistani firms are also excluded from the sample. Around 100 acquisitions have been taken place during 2004-2012 but only 51 of them were acquired by Pakistani firms and were listed on Karachi stock exchange (KSE). Out of these 2 financial and 13 non-financial firms were foreign companies, few were joint ventures, and data of few firms was not available. Three year pre and postacquisition data of 36 firms has been collected of each acquirer firm from the period of 2004 to 2012. Li et al, (2007) and Ang, (2010) investigated that firms with negative equity leads to financial distress, so those firms are also excluded from the sample 
The data of various financial and nonfinancial firms required for Data Envelopment Analysis (DEA) is obtained from annual reports of the firms published each year, financial statement analysis available at State Bank of Pakistan (SBP) and balance sheet analysis available at Karachi stock exchange. Input and output variables' data was extracted from that same source to calculate the firm technical and scale efficiency (Favero and Pepi,1995)

\section{Measurement of Cost Efficiency}

As this study investigates the cost efficiency of both financial and non-financial firms, there are different input and output variables for each. For calculating the cost efficiency of financial firms, two inputs are used, total deposits and Interest expense. The outputs include Total loans and Interest income. The inputs used for calculating the cost efficiency of non-financial firms include Total assets and Total stockholder's equity and output variables are Earnings before interest and tax (EBIT), Sales and Earnings after tax (EAT).

In this study the researchers have estimated the cost efficiency of consolidated firms by a means of DEA approach, a non-parametric approach based on convex combinations of firm in the sector. According to Charnes et al. 1994; Berger and Humphrey,1997, DEA technique has been widely used for estimating efficiency in diverse industries. There are two main reasons due to which we have adopted DEA approach; firstly it is the easiest method to decompose cost efficiency into technical and allocative efficiency and technical efficiency into pure technical efficiency/scale efficiency components. Secondly, the Malmquist approach is known as a standard technique used over the period of time to measure the progress of productivity and efficiency, based upon DEA.

\section{Data Envelopment Analysis (DEA)}

Charnes, Cooper Rhodes (1978) developed DEA evaluation method for efficiency by means of the constant-return to scale assumption. However, later Banker Cooper and Charnes In (1984) extended this approach, by means of the variable return to scale assumption to measure the firm efficiency. The free variable denoted by the Uo is one if the difference between these two models. However, DEA approach has power to make decision making unit (DMU) by merging the multiple inputs and outputs variables of a firm, and provides a single measure to determine the cost efficiency between inputs and outputs variables of the DMU.

DEA is based on the subsequent assumptions and this study has taken into account the below assumptions to run DEA.

1. DEA is unable to be applied on negative figures. So, all the figures should be positive.

2. DEA also cannot be applied on data if data set has noise in it. In previous studies, DEA has been often used for the measurement of efficiency of financial and nonfinancial firms.

In previous researches DEA has been extensively used to examine the efficiency of financial and non-financial firms. This research use DEA approach to calculate the technical and scale efficiency of the firms during 2004-2012 time horizons. Two of DEA model has been utilized in our investigation CRS model, and VRS model and then calculating scale efficiency by the ratio of these two models. Weights Inputs and outputs parameter are selected to enhance the efficiency score of each unit.

So when the DMU efficiency is one it is considered as efficient and the score of efficiency lies between the ranges of 0 to 1 . 


$$
\begin{gathered}
\theta=1 \text { Efficient } \\
\theta<1 \text { Inefficient }
\end{gathered}
$$

\section{Constant Return to Scale Model}

First model is the Constant Return to Scale Model or CCR model, as its name reveals that this is suitable when firm wants to maximize its technical efficiency from a specified level of inputs. But it is also possible to decrease inputs to achieve high efficiency. The Charnes et al. (1978) proposed a first mathematical equation as follow:

\section{Variable Return to Scale Model}

Banker, Charnes and Cooper (1984) presented another Variable Return to Scale Model or BCC Model that is used to attain a specified level of production by utilizing minimum amount of inputs. Scale Efficiency Model

$$
\text { Scale Efficiency }=\text { Technical efficiency under CRS }
$$

Technical efficiency under VRS

DATA ANALYSIS

Data has been analyzed for financial firms.

\begin{tabular}{|c|c|c|c|c|c|c|}
\hline \multirow[t]{2}{*}{ Company } & \multicolumn{3}{|c|}{ PRE } & \multicolumn{3}{|c|}{ POST } \\
\hline & $t-3$ & $t-2$ & $t-1$ & $t+1$ & $t+2$ & $t+3$ \\
\hline \multirow{2}{*}{$\begin{array}{l}\text { Standard Chartered Bank } \\
\text { First Capital Securities }\end{array}$} & 0.91879 & 1.00000 & 1.00000 & 1.00000 & 1.00000 & 1.00000 \\
\hline & 1.00000 & 1.00000 & 1.00000 & 1.00000 & 1.00000 & 1.00000 \\
\hline \multicolumn{7}{|l|}{ Corporation Limited } \\
\hline \multicolumn{7}{|l|}{ Standard Chartered Bank } \\
\hline & 1.00000 & 1.00000 & 1.00000 & 0.91328 & 0.86538 & 1.00000 \\
\hline \multicolumn{7}{|l|}{ Limited. } \\
\hline Summit Bank Limited & 1.00000 & 0.98738 & 1.00000 & 0.93554 & 0.63097 & 0.87161 \\
\hline Faysal Bank Limited & 1.00000 & 0.97105 & 0.84557 & 1.00000 & 0.73141 & 1.00000 \\
\hline Bank Islami Pakistan Limited & 0.59020 & 0.60514 & 0.52447 & 0.66090 & 0.51117 & 0.75666 \\
\hline \multirow[t]{2}{*}{ JS Bank Limited } & 0.71181 & 0.64271 & 0.68252 & 0.45068 & 1.00000 & 0.73132 \\
\hline & 0.888686 & 60.886611 & 0.864651 & 10.851486 & 60.819847 & 0.908513 \\
\hline \multicolumn{2}{|l|}{ Average } & \multicolumn{2}{|l|}{$\begin{array}{l}0.87998285 \\
7\end{array}$} & & \multicolumn{2}{|l|}{$\begin{array}{l}0.85994857 \\
1\end{array}$} \\
\hline
\end{tabular}

FINANCIAL FIRMS

INPUT ORIENTED CRS EFFICIENCY

The above table shows the CRS efficiency of firms for pre vs. post-acquisition years. As increase in efficiency is indicated by DMU more than 1 which is not observed in most cases. The average efficiency in the pre period is $87.99 \%$ while it decreased to an average of $85.99 \%$ in the post period. The difference between pre and post cost efficiency ( $2 \%)$ isdecreased as compared to the cost efficiency difference while including all firms $(5.151 \%)$. 
https://ir.iba.edu.pk/businessreview/vol11/iss1/7

DOI: https://doi.org/10.54784/1990-6587.1079

Business Review - Volume 11 Number 1

January - June 2016

\begin{tabular}{|c|c|c|c|c|c|c|}
\hline \multirow[b]{2}{*}{ Company } & \multicolumn{4}{|c|}{$\begin{array}{c}\text { FINANCIAL FIRMS } \\
\text { UT ORIENTED VRS EFFICIENCY }\end{array}$} & \multirow[b]{2}{*}{$\overline{\text { POST }}$} & \multirow[b]{3}{*}{$t+3$} \\
\hline & & PRE & & & & \\
\hline & $t-3$ & $t-2$ & $t-1$ & $t+1$ & $t+2$ & \\
\hline \multicolumn{7}{|l|}{ Standard Chartered Bank } \\
\hline & 1.00000 & 1.00000 & 1.00000 & 1.00000 & 1.00000 & 1.00000 \\
\hline \multicolumn{7}{|l|}{ Limited } \\
\hline \multicolumn{7}{|l|}{ First Capital Securities } \\
\hline & 1.00000 & 1.00000 & 1.00000 & 1.00000 & 1.00000 & 1.00000 \\
\hline \multicolumn{7}{|l|}{ Corporation Limited } \\
\hline \multicolumn{7}{|l|}{ Standard Chartered Bank } \\
\hline & 1.00000 & 1.00000 & 1.00000 & 1.00000 & 1.00000 & 1.00000 \\
\hline \multicolumn{7}{|l|}{ Limited. } \\
\hline Summit Bank Limited & 1.00000 & 0.99111 & 1.00000 & 0.93733 & 0.67570 & 0.92090 \\
\hline Faysal Bank Limited & 1.00000 & 1.00000 & 1.00000 & 1.00000 & 1.00000 & 1.00000 \\
\hline Bank Islami Pakistan Limited & 0.61215 & 0.80674 & 0.52479 & 0.83102 & 0.59963 & 0.75749 \\
\hline JS Bank Limited & 0.84734 & 0.82537 & 0.73462 & 0.75906 & 1.00000 & 0.79059 \\
\hline Average & 0.922784 & 0.946174 & 0.894201 & 0.932487 & 0.896476 & 0.92414 \\
\hline Averageof Pre and Post & & 0.9211 & & & 0.9177 & \\
\hline
\end{tabular}

The average VRS cost efficiency in the pre period was $92.11 \%$ while it decreased to $91.77 \%$ in the post period. Similarly when all the firms were included earlier in the calculation, the average efficiency decreased in the post period but now the difference in efficiency has decreased from $1.832 \%$ to $0.34 \%$. 
https://ir.iba.edu.pk/businessreview/vol11/iss1/7

DOI: https://doi.org/10.54784/1990-6587.1079

Business Review - Volume 11 Number 1

January - June 2016

\begin{tabular}{|c|c|c|c|c|c|c|}
\hline \multirow{2}{*}{\multicolumn{7}{|c|}{$\begin{array}{l}\text { FINANCIAL FIRMS } \\
\text { NPUT ORIENTED SCALE EFFICIENCY }\end{array}$}} \\
\hline & & & & & & \\
\hline & \multicolumn{4}{|c|}{ PRE } & \multicolumn{2}{|l|}{ POST } \\
\hline \multicolumn{7}{|l|}{ Company } \\
\hline & $t-3$ & $t-2$ & $t-1$ & $t+1$ & $t+2$ & $\mathbf{t}+\mathbf{3}$ \\
\hline Standard Chartered Bank Limited & 0.9188 & 1 & 1 & 1 & 1 & 1 \\
\hline \multicolumn{7}{|l|}{ First Capital Securities Corporation } \\
\hline & 1 & 1 & 1 & 1 & 1 & 1 \\
\hline \multicolumn{7}{|l|}{ Limited } \\
\hline Standard Chartered Bank Limited. & 1 & 1 & 1 & 0.9133 & 0.8654 & 1 \\
\hline Summit Bank Limited & 1 & 0.9962 & 1 & 0.9980 & 0.9338 & 0.9465 \\
\hline Faysal Bank Limited & 1 & 0.9710 & 0.8456 & 1 & 0.7314 & 1 \\
\hline Bank Islami Pakistan Limited & 0.9642 & 0.7501 & 0.9994 & 0.7953 & 0.8525 & 0.9989 \\
\hline JS Bank Limited & 0.8401 & 0.7787 & 0.9290 & 0.5937 & 1 & 0.9250 \\
\hline Average & 0.9604 & 0.928 & 0.9677 & 0.9000 & 0.9118 & 0.9814 \\
\hline Average of Pre and Post & & 0.9521 & & & 0.9311 & \\
\hline
\end{tabular}

The average efficiency in the pre period has increased from previous calculation to $95.21 \%$ while efficiency in the post period also increased but the difference between the pre and post has decreased from $3.196 \%$ to $2.1 \%$ after removing the problematic firms. On average, the firms are less efficient after acquisition as compared to before acquisition. 
https://ir.iba.edu.pk/businessreview/vol11/iss1/7

DOI: https://doi.org/10.54784/1990-6587.1079

Business Review - Volume 11 Number 1

January - June 2016

Non-Financial Firms

\begin{tabular}{|c|c|c|c|c|c|c|}
\hline \multicolumn{7}{|c|}{$\begin{array}{c}\text { NON-FINANCIAL FIRMS } \\
\text { INPUT ORIENTED CRS EFFICIENCY }\end{array}$} \\
\hline \multirow[t]{2}{*}{ Company } & \multicolumn{3}{|c|}{ PRE } & \multicolumn{3}{|c|}{ POST } \\
\hline & $t-3$ & $t-2$ & $t-1$ & $t+1$ & $t+2$ & $\mathbf{t}+3$ \\
\hline Nishat Chunian Limited & 1.00000 & 1.00000 & 1.00000 & 0.35201 & 0.36274 & 0.42354 \\
\hline Thal Limited & 1.00000 & 1.00000 & 1.00000 & 1.00000 & 1.00000 & 1.00000 \\
\hline Millat Tractors Limited & 0.90046 & 1.00000 & 1.00000 & 1.00000 & 1.00000 & 1.00000 \\
\hline Hub Power Company Limited & 0.63914 & 0.51531 & 0.56549 & 0.45339 & 0.45256 & 0.51649 \\
\hline \multicolumn{7}{|l|}{ Crescent Steel and Allied Products } \\
\hline & 0.38681 & 1.00000 & 0.62483 & 0.52412 & 0.57118 & 0.32630 \\
\hline \multicolumn{7}{|l|}{ Limited } \\
\hline Exide Pakistan Limited & 0.90715 & 1.00000 & 1.00000 & 1.00000 & 0.91386 & 1.00000 \\
\hline International Industries Limited & 1.00000 & 1.00000 & 1.00000 & 0.82196 & 0.56865 & 0.52803 \\
\hline JDW Sugar Mills Limited & 0.67371 & 0.87701 & 1.00000 & 0.83030 & 0.49382 & 0.58477 \\
\hline Average & 0.81341 & 0.92404 & 0.89879 & 0.74772 & 0.67035 & 0.67239 \\
\hline Average of Pre and Post & & 0.878746319 & & & 0.696822763 & \\
\hline
\end{tabular}

The above table shows the CRS efficiency of firms after removing the companies with negative input or output value and missing values. The average efficiency in the pre period is $87.87 \%$ while it decreased to an average of $69.68 \%$ in the post period. The difference between pre and post cost efficiency has increased as compared to the cost efficiency difference while including all firms. 


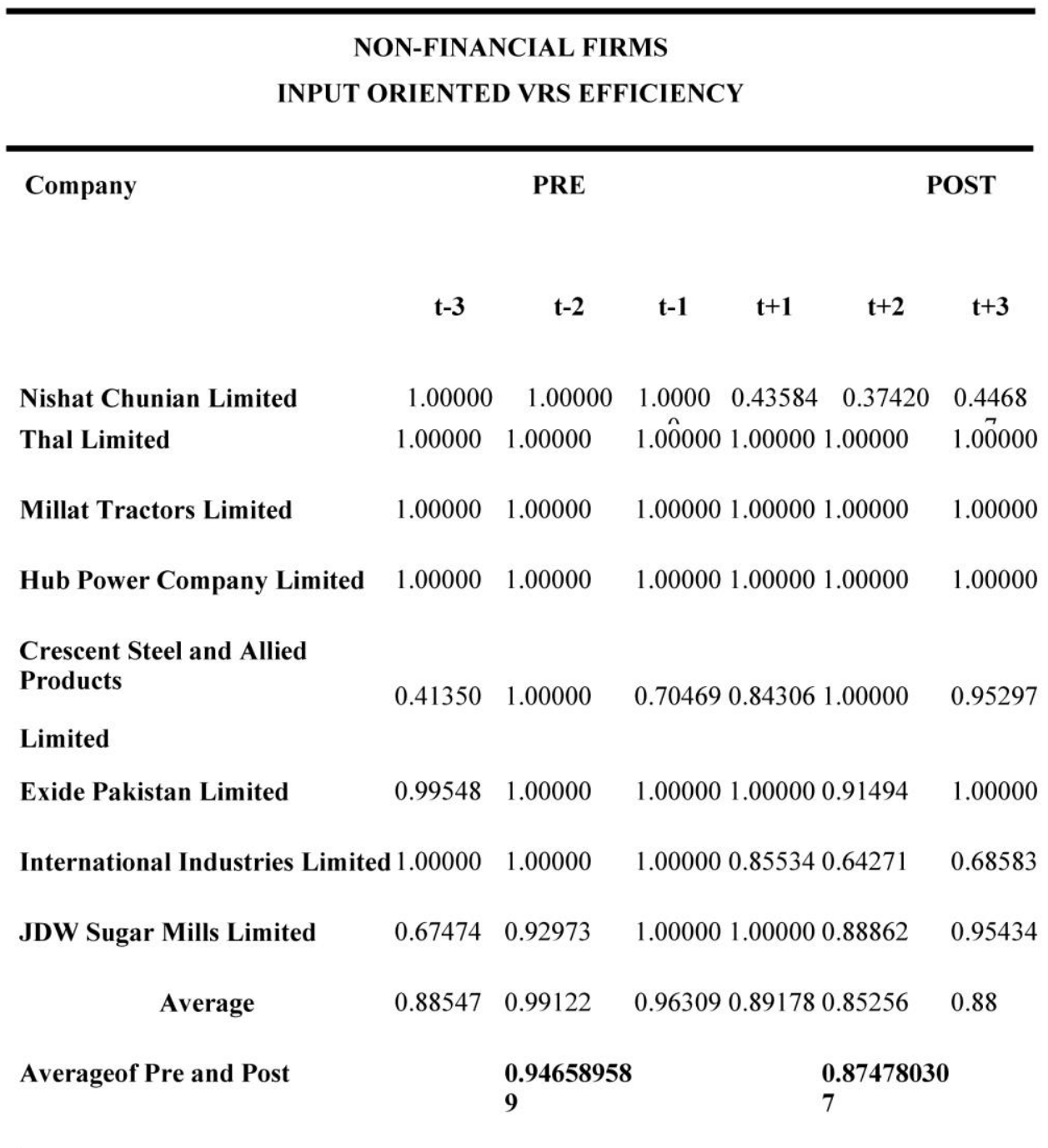

The average VRS cost efficiency in the pre period was $94.65 \%$ while it decreased to $87.47 \%$ in the post period. Earlier when all the firms were included in the calculation, the average efficiency decreased in the post period but now the efficiency has increased. 


\begin{tabular}{|c|c|c|c|c|c|c|}
\hline \multirow{3}{*}{ Company } & \multicolumn{4}{|c|}{$\begin{array}{l}\text { NON-FINANCIAL FIRMS } \\
\text { UT ORIENTED SCALE EFFICIENCY }\end{array}$} & \multirow{2}{*}{\multicolumn{2}{|c|}{ POST }} \\
\hline & \multirow[b]{2}{*}{$t-3$} & \multicolumn{2}{|c|}{ PRE } & \multirow[b]{2}{*}{$t+1$} & & \\
\hline & & $t-2$ & $t-1$ & & \multirow{2}{*}{$\begin{array}{l}\mathbf{t}+\mathbf{2} \\
0.22\end{array}$} & \multirow{2}{*}{$\begin{array}{l}\mathbf{t}+\mathbf{3} \\
0.74355\end{array}$} \\
\hline Nishat Chunian Limited & 1 & 1 & 1 & 0.80766 & & \\
\hline Thal Limited & 1 & 1 & 1 & 1 & 1 & 0.24255 \\
\hline Millat Tractors Limited & 0.90046 & 1 & 1 & 1 & 1 & 1 \\
\hline \multirow[t]{2}{*}{$\begin{array}{l}\text { Hub Power Company } \\
\text { Limited }\end{array}$} & 0.63914 & $\begin{array}{c}0.5153 \\
1\end{array}$ & 0.56549 & 0.45339 & 0.45256 & 0.51649 \\
\hline & 0.93547 & 1 & 0.88667 & 0.62169 & 0.57118 & 0.34241 \\
\hline $\begin{array}{l}\text { Limited } \\
\text { Exide Pakistan Limited }\end{array}$ & 0.91127 & 1 & 1 & 1 & 0.99882 & 1 \\
\hline $\begin{array}{l}\text { International Industries } \\
\text { Limited }\end{array}$ & 1 & 1 & 1 & 0.96097 & 0.88477 & 0.76991 \\
\hline JDW Sugar Mills Limited & 0.99847 & $\begin{array}{c}0.9432 \\
9\end{array}$ & 1 & 0.8303 & 0.55572 & 0.61275 \\
\hline Average & 0.9231 & $\begin{array}{c}0.9323 \\
2\end{array}$ & 0.93152 & 0.83425 & 0.71038 & 0.65346 \\
\hline Average of Pre and Post & & $\begin{array}{l}0.9289 \\
81955\end{array}$ & & & $\begin{array}{c}0.73269 \\
6472\end{array}$ & \\
\hline
\end{tabular}

The average efficiency in the pre period has increased from previous calculation to $92.89 \%$ while efficiency in the post period also increased to $73.26 \%$ but the difference between the pre and post has increased after removing the problematic firms. On average, the firms are less efficient after acquisition as compared to before acquisition.

We ranked the firms included in our data set in the categories of most efficient, less efficient and least efficient firms. The base of this ranking was their pre and post efficiencies over the period of time. 
https://ir.iba.edu.pk/businessreview/vol11/iss1/7

DOI: https://doi.org/10.54784/1990-6587.1079

Business Review - Volume 11 Number 1

January - June 2016

\section{Financial Firms}

\begin{tabular}{|c|c|c|}
\hline MOST EFFICIENT FIRMS & & INEFFICIENT FIRMS \\
\hline Allied Bank Limited & NIB Bank Limited & $\begin{array}{l}\text { Crescent Commercial Bank } \\
\text { Limited (Samba) }\end{array}$ \\
\hline Standard Chartered Bank Limited & Summit Bank Limited & JS Bank Limited \\
\hline $\begin{array}{l}\text { First Capital Securities } \\
\text { Corporation Limited }\end{array}$ & Faysal Bank Limited & Bank Islami Pakistan Limited \\
\hline \multicolumn{3}{|c|}{ Non - Financial firms } \\
\hline MOST EFFICIENT FIRMS & LESS EFFICIENT FIRMS & INEFFICIENT FIRMS \\
\hline $\begin{array}{l}\text { Indus Dyeing \& Manufacturing } \\
\text { Co. Limited }\end{array}$ & Saritow Spinning Mills Limited & $\begin{array}{c}\text { Pakistan Telecommunications } \\
\text { Company Limited }\end{array}$ \\
\hline Millat Tractors Limited & JDW Sugar Mills Limited & International Industries Limited \\
\hline Hub Power Company Limited & Exide Pakistan Limited & Byco Oil Pakistan \\
\hline Shahzad Textile Mills Limited & & $\begin{array}{l}\text { Crescent Steel and Allied } \\
\text { Products Limited }\end{array}$ \\
\hline \multirow[t]{4}{*}{ Pakistan Petroleum Limited } & & Dawood Lawrencepur \\
\hline & & Nishat Chunian Limited \\
\hline & & Dewan Cement Limited \\
\hline & & Byco Industries Incorporated \\
\hline & & Byco Petroleum Pakistan Limited \\
\hline
\end{tabular}

Published by iRepository, February 2021 


\section{Conclusion}

During last few decades significant amount of changes have been made in regulatory environment of financial institutions, which forced many of financial firms towards Acquisitions as a strategic tool for corporate restructuring. This study explored the impact of acquisitions on cost efficiency of financial and non-financial firms of Pakistan by using Data Envelopment Analysis (DEA) during 2004-2012.

Cost efficiency of the firm three year before (t-1, t-2 \& $\mathrm{t}-3)$ and three year after acquisition $(t+1, t+2, \& t+3)$ were calculated and compared (pre and post-acquisition) to examine increase or decrease in efficiency after consolidation. The efficiency of firm was measured by two major Data envelopment Analysis (DEA) models: CRS (constant return to scale) and VRS (variable return to scale) to obtain accurate results.

This study found statistically insignificant improvements in the cost efficiencies in the post- acquisition period for both financial and non-financial firms. The cost efficiency of financial firms showed a decrease of $1.8 \%$ in the post-acquisition period and non-financial firms showed a decrease of $7.85 \%$. These results are parallel with Al-Sharkas et al (2008) which also found related results for bank acquisitions in US. Sufian et al (2007) used the mutual estimation of non- parametric, parametric and ratio analysis to explore the efficiency effect of bank acquisitions in Singapore. Their results also showed no efficiency gains from Singaporean bank acquisitions.

The reasons for these insignificant results may be multiple. The efficiencies were negligible because the pre-acquisition efficiency was too high to have substantial improvement in cost efficiency in the post period. The financial firms face strict regulations of SBP for their survival and operations in Pakistan. Many firms are not in the position to undergo acquisition but they do so in order to stay in the market and protect themselves from liquidation or closure.

In most of the non-financial firms' acquisitions, the customers may not accept the transfer of ownership of their firm to another firm and shift to other firms. The brand loyalty to their brand firm affects the sales and profits of acquirer firms. Most of the acquisitions are done in unrelated industries and thus the economies of scale and synergy effect cannot be obtained as planned. Some of the firms acquired were in real financial distress and they drained the profitability and performance of the acquirer firms.

The institutions of government, policy developers and antitrust bodies may use these results while formulating and implementing policies regarding acquisitions in any sector or giving authorization for any acquisition application in the financial and nonfinancial sector of Pakistan. The authorities should use an appropriate approach in this regard and do complete cost and benefit analysis beforehand. The study suggests that as there is a significant decrease in the post- acquisition cost efficiency of both sectors so the acquisition applications and their future prospects should be analyzed carefully before giving approval. Such corporate control activities should improve the general efficiency and economic stability of the country.

There are many dimensions and areas of acquisition that can be studied. A few future research directions for the study include: Firstly, different inputs and outputs proxy can be 
used to measure firm's cost efficiency. Secondly, All acquirer firms either Pakistani or foreign can be used to investigate the impact of acquisitions on cost efficiencies, in order to increase the number of acquirer firms. Thirdly, we can conduct studies in different countries in order to compare the countries wise cost efficiencies. Fourthly, other efficiency measurement techniques or tools such as financial ratios, stochastic frontier analysis (SFA) and analytical hierarchal process (AHP) can be used to measure impact of acquisitions on cost efficiency of the firm. We used only DEA technique for cost efficiency in our study, multiple techniques can be used for comparison among them.

\section{References}

Adel A. Al-Sharkas, M. Kabir Hassan and Shari Lawrence (2008) The Impact of Mergers and Acquisitions on the Efficiency of the US Banking Industry: Further Evidence. Journal of Business Finance \& Accounting, 35(1-2), 50-70,

Akhtar, M. H. (2002). X-efficiency Analysis of Commercial Banks in Pakistan: A Preliminary Investigation. The Pakistan Development Review 41(4), 567-580.

Arnold, G. 1998. Mergers. Corporate Financial Management, Financial Times Pitman Publishing. 841-889.

Bauer, Paul W, Berger, Allen N, Ferrier, Gary D, \& Humphrey, David B. (1998). Consistency conditions for regulatory analysis of financial institutions: a comparison of frontier efficiency methods. Journal of Economics and Business, 50(2), 85-114.

Berger A. N., Hunter WC, Timme SG. (1993). The efficiency of financial institutions: a review and preview of research past, present, and future. Journal of Banking and Finance, $17(2-3), 221-249$.

Berger, A. N., Humphrey, D. B., (1997) Efficiency of Financial Institutions: International Survey and Directions for Future Research. European Journal of Operational Research, 98 (2), 175-212.

Cefis, E., S. Rosenkranz, and U. Weitzel, (2008) Effects of coordinated strategies on product and process R\&D, Journal of Economics,

Charnes, A., Cooper, W.W., Lewin, A., Seiford, L. (Eds.), (1994). Data Envelopment Analysis: Theory, Methodology, and Applications, Kluwer Academic Publishers, Boston, MA.

Chatterjee, S., (1986) Types of Synergy and Economic Value: The Impact of Acquisitions on Merging and Rival Firms, Strategic Management Journal 7, 119-139

Copeland, T. E., J. F. Weston, et al. 2007. Acquisitions, Divestitures, Restructuring, and Corporate Governance

Feinberg, R.M., (1985) Sales at Risk: A Test of the Mutual Forbearance theory of Conglomerate Behaviour, Journal of Business, 58, 225-241. 
Gourlay, A., G. Ravishankar, T. W. Jones. (2006). Non-Parametric Analysis of Efficiency Gains from Bank Mergers in India. Working Paper

Hitt, M.A., J.S. Harrison, and R.D. Ireland, (2001) Mergers and Acquisitions: A Guide to Creating Value for Stakeholders, Oxford University Press, Oxford

Houston, J.F., C.M. James, and M.D. Ryngaert, (2001) Where Do Merger Gains Come From? Bank Mergers from the Perspective of Insiders and Outsiders. Journal of Financial Economics, 60, 285-331

Huizinga, H.P., J.H.M. Nelissen, R.V. Vennet 2001. Efficiency Impact of Bank Mergers and Acquisitions in Europe, Discussion paper; Tinbergen Institute Amsterdam.

Jalal D. Akhavein, Allen N. Berger \& David B. Humphrey (1997) The Effects of megamergers on efficiency and prices: evidence from bank profit function. Forthcoming, Review of Industrial Organization, 12.

Khan M.S. \& A.S. Sendhaji 2000. Financial development and Economic Growth: An overview, Working paper; International Monetary Fund.

Kim, E. H., and V. Singal, (1993) Mergers and market power: Evidence from the airline industry. American Economic Review, 83, 549-569.

Lang, Günter, \& Welzel, Peter. (1999). Mergers among German cooperative banks: a panel based stochastic frontier analysis. Small Business Economics, 13(4), 273-286.

Lin, Ping-wen. (2005). An empirical analysis of bank mergers and cost efficiency in Taiwan, Small Business Economics, 25(2), 197-206.

Mahmood, A. and U. Loan 2006. Effects of financial Liberalization on the cost efficiency of Pakistani Banks. Pakistan Economic and Social Review, 44(1): 93-116.

Muhammad Ahmed and Zahid Ahmed, 2014. Mergers and Acquisitions: Effect on Financial Performance of Manufacturing Companies of Pakistan. Middle-East Journal of Scientific Research, 21 (4), 689-699.

Mukherjee, T.K., H. Kiymaz and H.K. Baker (2004) Merger Motives and Target Valuation: A Survey of Evidence from CFO‘s. Journal of Applied Finance, 14, 7-24

Peristiani, S. 1997. Do Mergers Improve the X-Efficiency and Scale Efficiency of U.S. Banks? Evidence from the 1980s. Journal of Money, Credit and Banking, 29(3), 326 - 337.

Prager, R. A., (1992) The effects of horizontal mergers on competition: The case of the Northern Securities Company. Rand Journal of Economics, 23, 123- 133. 
Qayyum, A. and S. Khan 2007. X-efficiency, Scale Economies, Technological Progress and Competition: A Case of Banking Sector in Pakistan. PIDE Working Papers, Pakistan Institute of Development Economics, Islamabad.

Rhoades, S. A. 1993. The Efficiency Effects of Horizontal Bank Mergers, Journal of Banking and Finance, 17, 411-22.

State bank of Pakistan 2003. Financial Sector Assessment 1990-2000. Karachi Pakistan.

Resti, Andrea. (1997). Evaluating the cost-efficiency of the Italian banking system: What can be learned from the joint application of parametric and non-parametric techniques.

Journal of Banking \& Finance, 21(2), 221-250.

Sapienza, P., (2002) The Effects of Banking Mergers on Loan Contracts. The Journal of Finance, 55, 329-367

Sufian and Fadzlan 2004. The efficiency effects of bank mergers and acquisitions in a developing economy: Evidence from Malaysia. International Journal of Applied

Econometrics and Quantitative Studies, 1(4), 53-74.

Sufian, \& Fadzlan 2007. Efficiency and Bank Merger in Singapore: A Joint Estimation of Non-Parametric, Parametric and Financial Ratios Analysis. Working Paper Wen, L.P. 2002. The Efficiency of Commercial bank Mergers in Taiwan: An Envelopment Analysis, International Journal of Management.

Worthington, A. C. 2001. Efficiency in Pre-Merger and Post-Merger Non-Bank Financial Institutions. Managerial and Decision Economics, 22(8), 439-452. 